War and the World 



\section{War and the World}

Military Power and the Fate of Continents

1450-2000

Jeremy Black

Yale University Press

New Haven and London 
Copyright (C) 1998 by Jeremy Black

First published in paperback 2000

All rights reserved. This book may not be reproduced in whole or in part, in any form (beyond that copying permitted by Sections 107 and 108 of the U.S. Copyright Law and except by reviewers for the public press) without written permission from the publishers.

Set in Adobe Garamond

Printed in Italy

Library of Congress Cataloging-in-Publication Data

Black, Jeremy.

War and the world, 1450-2000/Jeremy Black.

Includes bibliographical references and index.

ISBN 0-300-07202-3

1. Military history, Modern. 2. War and society-History.

3. History, Modern. 4. Europe-History. I. Title.

D214.B58 1997

$355^{\prime} .009-\mathrm{dc} 21$

A catalogue record for this book is available from the British Library. 
For Geoffrey Parker 
